\title{
Development and Application of Diversified School-enterprise Cooperation Model in English Teaching of Higher Vocational Colleges
}

\author{
Xiangmin $\mathrm{Li}$ \\ Foreign Language Department of Luohe Vocational Technology Colledge, 462000
}

Keywords: Diversification; School-enterprise cooperation; Higher vocational English

\begin{abstract}
School-enterprise cooperation is currently a method commonly used by Chinese universities to strengthen students' practical ability. Higher vocational colleges take cultivating students' professional ability and employment ability as the goal. School-enterprise cooperation have a more important practical significance for higher vocational colleges. How to do a good job in school-enterprise cooperation and make diversified school-enterprise cooperation become a way to improve the English proficiency of higher vocational college students is a problem worthy of our in-depth research and discussion.

Higher vocational education is an important part of China's higher education system. As a bridge link between school education and social employment, higher vocational education can provide a large number of professional talents for the development of the country and the society. In our country, the higher vocational education started relatively late. After continuous development and improvement in these years, we have made great progress and comprehensive improvement in terms of the construction of the teaching system and the curriculum. However, besides achievements, we should also face up to many problems in the development of higher vocational colleges. How to get rid of corruption and promote innovation to make higher vocational education can better serve the country's economic and social development and better provide students with a broad employment space is an era issue that all higher vocational colleges have to face.

School-enterprise cooperation has gradually entered various types of colleges and universities in China in recent years. It has become an effective way to improve students' social practice ability and improve their comprehensive ability. How to combine the deeper and broader school-enterprise cooperation with education and teaching to achieve a seamless connection between teaching and learning has a very important practical and social value, which is more instructive for higher vocational colleges.

Higher vocational English is a key component of higher vocational education. In the new transitional period of education, how to be able to move with the trend is not only the need for the development of education and teaching in the context of quality education, but also the internal needs for the survival and development of higher vocational colleges.
\end{abstract}

\section{Diversified School-Enterprise Cooperation Model}

The diversified school-enterprise cooperation model refers to the multi-modal and multi-channel cooperation method that centers on the improvement of students' post-practice ability between schools and related enterprises. Under the framework of diversified school-enterprise cooperation, according to the needs of colleges, enterprises provide schools with corresponding practical positions, so that students can improve their understanding and deepening the theory in operation and practice, and improve their own hands-on ability. Through cooperation with schools, enterprises can also learn more about the development of science and technology and the industry, and can solve their own labor input. At the same time, school-enterprise cooperation can also play a good role in publicity and promotion for enterprises. Extensive and in-depth school-enterprise cooperation is a win-win process for schools and enterprises. The method of school-enterprise cooperation is by no means immutable, but a process of development and evolution. The so-called diversification is not a fixed scope and space, but a process of constant development and constant innovation. The two sides of school-enterprise cooperation are mutually dominant. In the formulation of student practice programs, schools should make reasonable arrangements according 
to their own development needs and the characteristics of their disciplines. In the establishment of student posts, supervision and practical ability training, enterprises should play a leading role. Enterprises and schools can only realize the sustainable, healthy and in-depth cooperation and development of both parties only by playing their respective roles and rationally linking production and education.

\section{Significance of Diversified School-enterprise Cooperation in English Teaching of Higher Vocational Colleges}

The first thing that comes to mind of school-enterprise cooperation is the scene of a group of students who are busy in the workshop. The author has been engaged in English teaching in higher vocational education for many years. There have also been numerous exchanges with friends around on the issue of school-enterprise cooperation. In their impressions, machine processing and vehicle maintenance are the typical representatives of school-enterprise cooperation. But when it comes to English teaching in school-enterprise cooperation, they rarely know anything about it. For a long time, in people's traditional ideas, English teaching was limited to the classroom. The teaching mode of chalk and blackboard has continued for many years, and this scene has left in many people's memory of English teaching. In the division of subjects, English is often classified in liberal arts. What are liberal arts? Liberal arts are not quiet or the pronouns of inflexible and obsolete. On the contrary, English is a very practical course. First of all, English itself is a communication tool. Learning English is not simply a matter of understanding the vocabulary or the grammar, it should be applied to practice and in the communication with people, to achieve the purpose of information transfer and emotional communication. Second, with the development of our country's economy and society, English has gone deep into the corners of people's lives. English has become a kind of popular knowledge, not a treasure in the attic, which provides a possible and broad space for English to go out. Finally, the booming demands in enterprses to professional English talents continue to drive the socialization of English. Under the tide of economic globalization and informatization, there is no enterprise that can be independent and exist alone as an isolated individual. This is true even for the traditional enterprises in everyone's opinion. When you walk along the streets, English is everywhere from the packaging of snacks and the label of clothes. The universality of English can be seen.

In English teaching of higher vocational colleges, school-enterprise cooperation starts relatively late compared with other disciplines. At present, many aspects are still in the stage of exploration. There are still many immature places in theory and practice. However, the development of English teaching of higher vocational colleges is a kind of progress. This kind of progress is first an improvement in the way of thinking. It gives people a new understanding of higher vocational English education and teaching in the new era with a brand-new attitude. Second, this progress has awakened the attention of the whole society to higher vocational English teaching, making enterprises and society have a comprehensive understanding of our teaching ability and making plans on this basis to make us see our own shortcomings and deficiencies. Finally, the school-enterprise cooperation of English teaching in higher vocational colleges expands the space for English teaching, which has given fresh impetus to the long-term development of this discipline.

\section{Current existing Problems in English Teaching in School-Enterprise Cooperation}

At present, the school-enterprise cooperation in our country is still in a stage of development and improvement. There are various problems that are inevitable. According to the author, the current existing problems in English teaching in school-enterprise cooperation are as follows:

Many Enterprises are still Lack of Motivation to Cooperate. For colleges and enterprises, the school-enterprise cooperation is a win-win process. However, from the aspect of initiative, colleges are dominating and are usually actively looking for cooperation. For safety and efficiency considerations, most enterprises are reluctant to arrange students with weaker practical skills in important positions or key areas. Some enterprises have a greater degree of self-reliance in 
school-enterprise cooperation. In the name of school-enterprise cooperation, they are actually purely to increase their visibility and benefit from it. The goals of colleges and enterprises are different. Colleges aim at teaching and education, while enterprises are more in pursuit of social benefits.

Many Enterprises have Prejudice to Students of Vocational Colleges. Frankly speaking, in China's higher education system, vocational colleges are indeed in a very disadvantageous position in recruiting students, which is hard to change in short term. Many people have different eyes on vocational college students, thinking that their knowledge is limited and their abilities are not high. The author once had contact with many enterprises and could feel from the commutation with them that they are skeptical about the ability and quality of students in higher vocational colleges. Some people even think that students in vocational colleges are just trying to get the diplomas or killing time. For professional reasons, the author once had contact with a local tourism company. The person in charge of this company was directly said that if the English level of vocational college students are not enough, they will do harm to the reputation of the company. This kind of prejudice has been for a long time and cannot be changed in a short time.

Low Level of Cooperation and Low Effectiveness. Outline for National Medium-Term and Long-Term Talent Development Planning (2010-2020) formulated by the state clearly states that it is necessary to gradually improve the highly skilled personnel training system that is based on enterprises, vocational colleges, and closely combines school education with enterprise training. The current school-enterprise cooperation is basically composed of two aspects: colleges and enterprises. When there are problems in cooperation between the two which cannot be promoted, there is no coordinated intervention by relevant functional departments. Many problems cannot be effectively solved by the strength of colleges or enterprises. How to ensure the proper interests of enterprises in school-enterprise cooperation and how to protect the vital interests of students are the issues that we have to face and solve. To promote school-enterprise cooperation to a higher level, it is necessary to make efforts in the aspects of management system, operation control, and policy guarantee to effectively improve the effectiveness of school-enterprise cooperation.

\section{Diversified School-Enterprise Cooperation Model Based on English Orientation in Higher Vocational Education}

In order to do a good job in English teaching in school-enterprise cooperation of higher vocational colleges, the author believes that efforts should be made in the following areas:

Local Government should Give Full Play to its Leading Role. In the school-enterprise cooperation, the government should play more roles, give full play to the service and guidance functions, build a bridge between colleges and enterprises, create a platform suitable for school-enterprise cooperation, and actively promote the exchanges and cooperation between the two, cultivate high-quality talents which adapt to local economic development, set up special organizations to govern and standardize cooperation treaties, supervise the responsibilities and obligations between colleges and enterprises, and ensure that the cooperation and exchange can be carried out orderly and smoothly. For example, in the promotion of English programs for the local tourism project, the planning and implementation of the project can be assigned to colleges, so that as many students as possible are involved. Everyone contributes ideas and contributes to the construction of the plan. Based on the project, the local tourism service company can carefully plan the links which are suitable for students to participate in. In this way, related enterprises do not only reduce costs, but also ensure the smooth implementation of the project. The students' abilities have been greatly improved in project implementation.

Try to Set up a Professional Service Group. Professional service groups may be new to English majors, but they are no strangers to the hotel services profession. In recent years, many localities have relied on local education resources, and have used the specialty of colleges as a link and support. They have also formed professional service groups with local enterprises and even the enterprises of other places. For example, Shanghai took the lead in establishing Shanghai Business Group with Shanghai Business School as the leader and the major Shanghai-based trade enterprises 
as the core. There are many such kind of professional service groups, most of which have achieved very good social and economic benefits. These professional service groups combine the advantages of their own constituent elements in a clever way to form a benefit-sharing community.

Reform Higher Vocational English Curriculum System. Higher vocational English curriculum system reform should follow the following principles. First of all, regardless of content or progress setting, the curriculum system should aim at improving students' professionalism. The teaching content is selected according to the requirements of professional posts and typical tasks, and the teaching process is carried out according to the professional activities and work processes corresponding to the course. In the teaching process, set learning situation according to the simulation of the real working environment as much as possible. Organically connect the knowledge, ability and quality required for professional positions in teaching and provide all-round, three-dimensional education for students. Various vocational colleges can, according to their actual conditions, organize teachers to prepare English teaching materials which are suitable for operations. The categories can be as detailed as possible, such as oral materials, listening materials and writing materials. Only the teaching materials are appropriate, can we use them in education and teaching to develop practical and targeted training so that students can apply what they have learned.

Do Full Social Research. This part of social research is often easily overlooked by everyone. There should be adequate social research in English teaching of school-enterprise cooperation in higher vocational colleges. Social research can be done locally or in other places. The choice of region depends mainly on the area where the school-enterprise cooperation is carried out. Of course, if school-enterprise cooperation can be carried out locally, it is generally the best choice for both parties. Colleges and professional colleges in English should carefully screen before coming into contact with enterprises to decide which enterprises are more suitable for organizing students for practical activities and which positions are more suitable for students' actual operations. Try to evade the positions that have great impact on enterprises or have threat to the safety of students. If there is a specific implementation, we must do scientific and rigorous steps. Social research should run through the education and teaching. Colleges should regularly organize relevant professional teachers to actually inspect and investigate enterprises to understand the talent needs. We can even formulate education and teaching plans based on this, and we will fill in gaps in discussions and exchanges with corporate training specialists to improve related teaching content based on National Vocational Qualification Standard.

Construct a Three-Dimensional Evaluation Mechanism for English Curriculum. Assessment and learning are inseparable. The English assessment and evaluation mechanism under the school-enterprise cooperation mode must be consistent with the actual requirements. This evaluation system should be three-dimensional, scientific, and can effectively promote the development of English teaching in higher vocational education. In general, it should be composed of three parts: schedule course, internship, and later improvement. The score allocation ratio can be adjusted according to different learning stages. The daily course results are mainly directed at the usual classroom teaching. This part of the evaluation system is relatively mature. After all, we have mainly adopted this assessment method over years. The appraisal and score of the two parts which are internship and later improvement should be rationally designed according to the characteristics of the course.

\section{Conclusion}

The continuous development of our country's economy and society has increased the need for professional talents, which is a major development opportunity for higher vocational colleges. But opportunities do not equate to achievements. If we cannot seize the opportunity and stop, it is only a matter of time before we are eliminated by the times. Nowadays, in the tide of education transformation and reform, how to use the school-enterprise cooperation model in teaching and education is concerned with the survival and development of higher vocational colleges. Higher vocational English teaching should be based on the sense of urgency and mission of self-responsibility to do a good job of both theoretical and practical work, and strive to promote the 
deep development of school-enterprise cooperation.

\section{References}

[1] Shi Hong, Zhou Qun. Study on the Teaching Material Construction Strategies of Higher Vocational Education from the Perspective of School-enterprise Cooperation [J]. Education and Occupation. 2011(12).

[2] Zhao Zhiqun. Vocational Education Integrated Work and Learning Curriculum Development Guide [M]. Beijing: Tsinghua University Press, 2009.

[3] Han Zhigang, Jin Changyi. Discussion on the Operational Mechanism of School-Enterprise Cooperation [J]. Guangxi Light Industry, 2008 (6).

[4] Wu Mancai. Innovate School-enterprise Cooperation Mechanism to Achieve Deep Integration of Schools and Enterprises. China Higher Vocational Education Network, 2011.

[5] Liu Yanming, Liu Lei. The Current Situation and Countermeasures of School-enterprise Cooperation in Higher Vocational Colleges. China Electric Power Education, 2009, (8):58-60.

[6] He Xiuyan. Constructing a Model of School-enterprise Cooperation in Higher Vocational Education with Stakeholders' Joint Governance [J]. Educational Theory \& Practice, 2008, (33).

[7] Ma Chengrong. Research on School-enterprise Cooperation Model [J]. Education and Occupation, 2007, (23): 8-10.

[8] Wu Yan. Combining Production with Education to Solve the Bottleneck of Higher Vocational Development [J]. Chinese Vocational and Technical Education, 2005, (22). 